\title{
Unit Commitment Taking into Account Reactive Power
}

\author{
Xiangjun Li Student Member (Kitami Institute of Technology, xjLi79@yahoo.co.jp) \\ Susumu Yamashiro Senior Member (Kitami Institute of Technology, yama@elec.kitami-it.ac.jp)
}

Keywords: unit commitment, power market, reactive power, voltage control, optimal power flow, LMP

Over the past several decades, stability, reliability, and economy of the electric power system have been maintained well under the vertically integrated electric power system which combines the power generation, transmission, and distribution all together. The thermal UC schedule, one of the main themes in the system scheduling, had been aimed at minimizing the operating cost including fuel and start-up costs. However, due to the deregulation and liberalization developed in the power industry worldwide, especially in the power generation department, free access to a transmission network is realized under the free competition of the generation and retailing of electric power in the electric power market

Under such new circumstances, we can expect a non-profit system operating organization, such as Independent System Operator (ISO) in the United States, to monitor the system operation concerned with supply-demand balance and security maintenance. However, how we maximize profits will be one of the important issues for power generation companies (Genco) participating in the power market, when they try to supply a certain amount of energy to a system.

Moreover, Transmission Access Charge (TAC) and Ancillary Services Charge (ASC) might be given consideration as expenditures of Gencos in addition to the operating cost of unit, such as the fuel and start-up costs when the operating cost of Genco is evaluated under the above mentioned competing environment. Meanwhile, many UC methods that argue the economic operation schedule under various constraints such as operating constraints of unit and security constraints of power system etc. have been discussed so far, but they are mostly concerned with real power and the UC problem including an economy of reactive power has been hardly discussed.

From above discussions, we developed a UC method, taking into account reactive power under the following assumptions: i) Power market cleaning price is determined by Locational Marginal Price (LMP); ii) Power transmission and voltage control are managed by a monopoly transmission company (Transco) and a non-profit organization such as the ISO; iii) Voltage at load node is maintained by the Var compensating equipment and this cost is paid by market participants as an ASC; iv) Also TAC is imposed on market participants including consumers.

In this paper, we first defined a benefit maximized objective function which includes both TAC and ASC as operating cost in addition to the unit's fuel and start-up costs. Then, to realize an optimum UC schedule, we developed a Voltage Magnitude Constraint-OPF (VMC-OPF) which deals with two types of constraints of line flow and bus voltage magnitude (see Fig. 1 and Appendix). Using the iterative optimization method of Ref. (1) and VMC-OPF, we developed a UC scheduling algorithm taking into account reactive power.

Applying the proposed method to the IEEE 118 bus system and investigating the simulation results, we confirmed the effectiveness of our method.

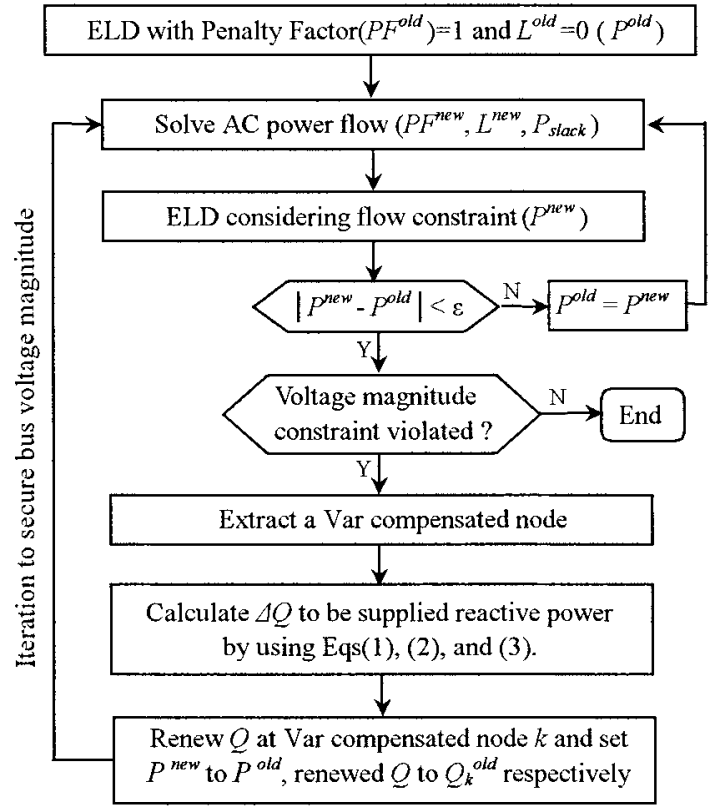

Fig. 1. VMC-OPF procedure

\section{Appendix}

(1) Calculation of $\Delta Q$

$$
\Delta Q=-\gamma \cdot \Delta V \cdot \frac{1}{\partial Z / \partial Q} \cdots \cdots \cdots \cdots \cdots \cdots \cdots \cdots \cdots
$$

(2) Calculation of $\partial Z / \partial Q$

- Voltage magnitude violation for upper limit

$$
\frac{\partial Z}{\partial Q_{j}}=\frac{\partial\left(V_{j}-\overline{V_{j}}\right)}{\partial Q_{j}}=\frac{1}{-\sum_{i \neq j} V_{i} b_{i j} \cos \theta_{i j}} \cdots \cdots \cdots
$$

- Voltage magnitude violation for lower limit

$$
\frac{\partial Z}{\partial Q_{j}}=\frac{\partial\left(\underline{V}_{j}-V_{j}\right)}{\partial Q_{j}}=\frac{1}{\sum_{i \neq j} V_{i} b_{i j} \cos \theta_{i j}} .
$$

where, $Z$ : vectors of line flow and voltage magnitude, $\bar{V}$ : upper limit of voltage magnitude, $\underline{V}$ : lower limit of voltage magnitude, $b$ : line susceptance, $\theta$ : phase angle, $\Delta Q$ : supplied reactive power at Var compensated node, $\gamma$ : convergent accelerating coefficient and $\Delta V$ : difference between rated voltage and calculated voltage.

\section{References}

( 1 ) G. Zhao and S. Yamashiro: "A Method for Unit Commitment with Transmission Losses and Flow Constraint", J. Elect. Enging Jpn, Vol.142, No.4, pp.9-19 (2003-3) 


\section{無効電力を考慮した発電機起動停止計画法}

学生員 李 相俊* 上級会員 山城 迪*

\section{Unit Commitment Taking into Account Reactive Power}

Xiangjun $\mathrm{Li}^{*}$, Student Member, Susumu Yamashiro*, Senior Member

In this paper, a Voltage Magnitude Constrained OPF (VMC-OPF) algorithm to determine the reactive power injection from compensating equipment to load bus is developed. By introducing the proposed VMC-OPF to the real power related Unit Commitment (UC) ${ }^{(1)}$, a novel daily UC method taking into account the reactive power to secure bus voltage magnitude is presented. The Transmission Access Charge (TAC) and Ancillary Services Charge (ASC) are included in the objective function for considering costs of using transmission network and supplying reactive power to maintain the voltage. Using the proposed UC, the difference between two schedules based on benefit maximization and cost minimization is also discussed. To demonstrate the effectiveness of the proposed UC method, we demonstrate various simulation results for a model power system of IEEE-118 bus system.

キーワード : 起動停止計画, 電力市場, 無効電力, 電圧制御, 最適潮流計算, 地点別限界価格

Keywords: unit commitment, power market, reactive power, voltage control, optimal power flow, LMP

\section{1. まえがき}

過去, 数十年にわたって電力系統の安定性・信頼性・経済 性は発・送・配電を一括した垂直統合型電力体制のもとで 維持され，系統運用計画の主要なテーマである火力発電機 の起動停止計画（UC）は，火力の然料費と起動費からなる 系統全体の運転コストの最小化を目的としていた。しかし ながら，世界的に発電部門を始めとする電気事業の規制緩 和・自由化 ${ }^{(2)(3)}$ が進展し, 電力市場の存在を前提として発 電および小売部門の自由競争下での, 送電線への自由なア クセスが認められるようになってきている。このような新 しい環境の下で, 非営利型の系統運用機関による需給調整, 電力品質の維持などに関する系統運用が期待されるが(4), 市 場に参加する発電会社にとっては, 一定の電力量を系統に 供給しようとする場合，どのようにして収入と支出（運用 コスト）の差からなる利益の最大化を困るかが重要な課題 になる。また，競争環境下で発電会社の運用コストを評価 する際には，燃料費等のユニットの運転コストに加えて送 電線アクセスに伴うネットワーク使用料金（TAC）や系統 セキュリティ維持のためのアンシラリサービス料金 (ASC) 等を考慮する必要がある。

一方, 従来の有効電力に注目した火力発電機起動停止計

\footnotetext{
* 北見工業大学 電気電子工学科

厂 090-8507 北見市公園町 165 番地

Department of Electrical and Electronic Engineering, Kitami Institute of Technology, 165, Koen-cho, Kitami 090-8507
}

画においては，ユニットの運転制約や系統のセキュリティ 制約などが考慮されてきたが(5) (9), 電圧維持に係る無効電 力供給の経済性 ${ }^{(10)}$ を考慮した UC 計画法は筆者等の知る限 りでは見当たらない。

表題のテーマを議論する本論文では，まず，短期限界費 用に基づく LMP(地点別限界価格）によって市場の電力が 取引され, 発電会社とは独立した送電会社と非営利型の系 統運用機関のもとで電力の輸送がなされ, かつ, 調相設備に より負荷母線電圧が維持される電力システムの運用を想定 する。次に, このような電力供給システムにおいて, 市場 に参加する発電会社の利益最大化を目的とする, 無効電力 を考慮した発電機起動停止計画決定手法について考察する。 自由化に伴う電力市場の構成としては, 設備容量など規模 的に類似した複数の発電会社が参加する場合, あるいは, 相 対的に規模の大きい発電会社と小規模な複数の発電会社が 参加する場合など, 様々なケースが考えられるが, ここで は後者, 即ち, 相対的に極めて大きな電力量を供給する発 電会社 (以下, 主発電会社) の存在を想定し, (1)負荷母線の 電圧維持を目的とする調相設備投入量の決定アルゴリズム を採り入れた電圧維持制約付き最適潮流計算 (VMC-OPF： Voltage Magnitude Constrained-OPF) を開発する。(2)これ による負荷母線での無効電力供給と送電線無効潮流の経済 性評価を考慮した主発電会社における日間の起動停止計画 決定法について考察する。

以下，はじめに，目的関数の定義と関連する有効・無効 電力の LMP および TAC の算定法について述べる。次に, 
無効電力を考慮した起動停止計画の決定および VMC-OPF の計算アルゴリズムについて言及した後，モデル系統を用 いて提案手法の有効性を検証する。

\section{2. 問題の記述と定式化}

$\langle\mathbf{2} \cdot \mathbf{1}\rangle$ 目的関数 筆者等は文献 (1)において, 有効電 力を対象に，各種の制約条件を満たした上で，電力市場に おける発電会社の運転コストと収入とからなる利益の最大 化を目的とする発電機起動停止計画を考察したが，ここで は, 発電会社の収入は有効電力の供給によって得られるも のとし，送電線アクセスに伴う $\mathrm{TAC}$ と電圧維持に関する ASC を考慮した次の目的関数を導入する。

$$
M A X \Omega=\sum_{t=1}^{T} \sum_{i}\left(\rho_{i} P_{i}-F_{i}\right)-\sum_{i} F S_{i}-\sum_{t=1}^{T} v R-\sum_{t=1}^{T} \alpha A
$$

ここで,

$$
\begin{aligned}
& \Omega: \text { 発電会社の収益 } \\
& t: \text { 時間带 } \\
& T: \text { 考察期間 } \\
& i: \text { 発電機ノード } \\
& \rho: \text { 有効電力に関する LMP } \\
& P: \text { 有効電力 } \\
& F: \text { 燃料費 }(\text { 付録参照 }) \\
& F S: \text { 起動費 (付録参照 })
\end{aligned}
$$

$R$ : ネットワーク使用料金（TAC）

$v$ : 発電会社と需要家間の TAC の分担割合 $(0 \leqq v \leqq 1)$

$A$ : 電圧維持に関するアンシラリサービス料金 $(\mathrm{ASC})$ $\alpha$ : 発電会社と需要家間の ASC の分担割合 $(0 \leqq \alpha \leqq 1)$

なお，(1) 式では簡単化のため $\rho, P, F, R, A$ における 時間帯 $t$ の添字は省略している。

また，運用計画制約条件としては，発電機の出力変化率 や無効電力出力制約なども考えられるが，本論文は負荷母 線での電圧維持等に係る無効電力供給の経済性評価を含む 計画法の開発を主目的としており，簡単化のため以下の制 約を考慮するものとする。

(1) 需給バランス制約：

$$
\sum_{i=1}^{M} P_{i}=\sum_{j=M+1}^{N} P_{j}+L
$$

（2）母線 $j$ の電圧制約：

$$
\underline{V}_{j}<V_{j}<\overline{V_{j}}
$$

（3）運転予備力制約（OR 制約）：

$$
\sum_{i=1}^{M} \overline{P_{i}} \geq\left(\sum_{j=M+1}^{N} P_{j}+L\right)(1+O R)
$$

（4）線路容量制約：

$$
\left|W_{l}\right| \leq \overline{W_{l}}
$$

（５）最小運転時間（MUT)，最小停止時間（MDT）制約 ここで, $i$ および $j$ は各々発電機および負荷母線を表し, また，
$L ：$ 送電損失
$\bar{P}:$ 発電機出力の上限值
$P:$ 発電機出力の下限值
$M$ : 発電機母線数
$N$ : 系統の全母線数
$\bar{V}$ ：電圧大きさの上限值
$V:$ 電圧大きさの下限值
$W_{l}:$ 線路 $l$ の線路潮流
$\overline{W_{l}}:$ 線路 $l$ の線路容量
$O R$ : 運転予備率

$\langle 2 \cdot 2\rangle$ 有効・無効電力の LMP の算定 いま, 限界費 用に基づいて時々刻々の電力価格が決まるものとすれば, ネットワーク参加者の社会厚生を最大にする有効・無効電 力に関する地点別限界費用は次のようになる ${ }^{(11)}$ 。

$$
\begin{aligned}
& \rho_{n}=\lambda\left(1-\frac{\partial L}{\partial P_{n}}\right)+\sum \mu \frac{\partial Z}{\partial P_{n}} \\
& \sigma_{n}=-\lambda \frac{\partial L}{\partial Q_{n}}+\sum \mu \frac{\partial Z}{\partial Q_{n}} \cdots
\end{aligned}
$$

ここで，

$$
\begin{aligned}
& n: \text { ノド番号 } \\
& \sigma: \text { 無効電力に関する LMP } \\
& \lambda: \text { 需給バランスに関するラグランジュ未定乗数 } \\
& Z: \text { 線路潮流および電圧制約ベクトル } \\
& \mu: Z \text { に関するラグランジュ未定乗数 }
\end{aligned}
$$

また，(6)，(7) 式では， $L$ および $Z$ の有効電力 $P$ および 無効電力 $Q$ に関する増分量を計算する必要があり, これら の算定法を以下に示す。

$\langle 2 \cdot 2 \cdot 1\rangle \partial L / \partial P, \partial L / \partial Q$ の算定 有効・無効電力に 関する増分損失 $(\partial L / \partial P, \partial L / \partial Q)$ は Happ の方法を参考 にし，次式から求めるものとする ${ }^{(12)}$ 。

$$
\left[\begin{array}{l}
\frac{d L}{d P} \\
\frac{d L}{d Q}
\end{array}\right]=\left[\begin{array}{cc}
J_{P \theta}^{T} & 0 \\
0 & J_{Q V}^{T}
\end{array}\right]^{-1}\left[\begin{array}{l}
\frac{d L}{d \theta} \\
\frac{d L}{d V}
\end{array}\right] .
$$

ここで, $J_{P \theta}^{T}$ は $\partial P / \partial \theta$ を要素とする行列の，また， $J_{Q V}^{T}$ は $\partial Q / \partial V$ を要素とする行列の転置を示す。

また，全系統での有効電力の損失 $L$ は (9) 式のように示 すことができるので ${ }^{(13)}$,

$$
L=\sum_{i=1}^{N} \sum_{j=1}^{N} V_{i} V_{j} G_{i j} \cos \left(\theta_{i}-\theta_{j}\right)
$$

電圧位相角・大きさに関する増分損失 $(\partial L / \partial \theta, \partial L / \partial V)$ は,

$$
\begin{aligned}
& \frac{\partial L}{\partial \theta_{i}}=-2 \sum_{j=1}^{N} V_{i} V_{j} G_{i j} \sin \left(\theta_{i}-\theta_{j}\right) \\
& \frac{\partial L}{\partial V_{i}}=2 \sum_{j=1}^{N} V_{j} G_{i j} \cos \left(\theta_{i}-\theta_{j}\right) \cdots
\end{aligned}
$$


のようになる。ここで，Gはブスアドミンタンス行列の実 数部, $\theta$ は電圧位相角を示す。

$\langle\mathbf{2} \cdot \mathbf{2} \cdot 2\rangle \quad \partial Z / \partial P, \partial Z / \partial Q$ の算定 線路潮流および電 圧制約ベクトル $Z$ の $P, Q$ に関する変化量に関しては，系 統における $P$ と位相角 $\theta, Q$ と電圧（大きさ） $V$ との間の 密接な関係を考慮して，ここでは，線路潮流制約について は有効電力により $\partial Z / \partial P$ を, 電圧制約に関しては無効電力 により $\partial Z / \partial Q$ を求めるものとする。

（1） $\partial Z / \partial P$ の算定法 線路潮流が電圧位相角で支配 される有効潮流で表されるものとすると，ノード電力 $P$ に よって線路潮流は (12) 式で表されるので，これから， $\partial Z / \partial P$ を容易に計算することができる。

$$
Z=F H\left(H^{T} F H\right)^{-1} P
$$

ここで，

$F:$ 線路 $l$ のセプタンス $b_{l}$ を要素とする対角行列

$H$ : 線路潮流の始端を +1 , 終端を -1 , その他を 0 と する線路とノード間の接続行列

（2） $\partial Z / \partial Q$ の算定法 母線電圧の制御には，発電機 の自動電圧調整器 $(A V R)$ や負荷時タップ切替変圧器 (LRT) などの導入が考えられるが，ここでは，AVRやLRTによ り系統電圧が目標值に維持されている状況下で，負荷変動 によって生じる電圧制約違反を当該母線での調相設備によ り対応する場合を考える。いま, $\theta_{i j}=\theta_{i}-\theta_{j}$, 線路アドミ ンタンスを $g_{i j}-j b_{i j}=1 /\left(r_{i j}+j x_{i j}\right)$ とすると, 母線 $i$ から $j$ への電力は次のようになる。

$$
\begin{aligned}
P_{i j}+j Q_{i j}= & \dot{V}_{i} \dot{I}_{i j}^{*}=\dot{V}_{i}\left[\left(\dot{V}_{i}-\dot{V}_{j}\right)\left(g_{i j}-j b_{i j}\right)\right]^{*} \\
= & V_{i}^{2}\left(g_{i j}+j b_{i j}\right)-V_{i} V_{j}\left[\left(g_{i j} \cos \theta_{i j}-b_{i j} \sin \theta_{i j}\right)\right. \\
& \left.+j\left(g_{i j} \sin \theta_{i j}+b_{i j} \cos \theta_{i j}\right)\right] \ldots \ldots \ldots \ldots(13)
\end{aligned}
$$

従って,

$$
Q_{i j}=V_{i}^{2} b_{i j}-V_{i} V_{j}\left(g_{i j} \sin \theta_{i j}+b_{i j} \cos \theta_{i j}\right) \cdots \cdots
$$

いま，抵抗 $r_{i j}$ はリアクタンス $x_{i j}$ に比べ十分小さいもの と仮定すれば，上式は，

$$
Q_{i j}=V_{i}^{2} b_{i j}-V_{i} V_{j} b_{i j} \cos \theta_{i j}
$$

従って,ノード $j$ に系統から流入する無効電力 $Q_{j}$ は, $I_{i j}$ を線路電流の大きさとすると

$$
Q_{j}=\sum_{i \neq j}\left(Q_{i j}-I_{i j}^{2} x_{i j}\right)=\sum_{i \neq j}\left(V_{i}^{2} b_{i j}-V_{i} V_{j} b_{i j} \cos \theta_{i j}-I_{i j}^{2} x_{i j}\right)
$$

上式から，ノード $j$ の母線電圧は次のように表される。

$$
V_{j}=\frac{Q_{j}+\sum_{i \neq j}\left(I_{i j}^{2} x_{i j}-V_{i}^{2} b_{i j}\right)}{-\sum_{i \neq j} V_{i} b_{i j} \cos \theta_{i j}} .
$$

ここで, 線路潮流は有効潮流が支配的で，かつ， $V_{i}$ は $Q_{j}$ の変化に大きく影響されないとすれば，近似的に，

$$
\frac{\partial V_{j}}{\partial Q_{j}}=\frac{1}{-\sum_{i \neq j} V_{i} b_{i j} \cos \theta_{i j}}
$$

となるので, (7) 式での $\partial Z / \partial Q$ は電圧の上, 下限制約に対 して，各々 (19)，(20) 式のようになる。

（i）母線電圧の上限制約に関しては,

$$
\frac{\partial Z}{\partial Q_{j}}=\frac{\partial\left(V_{j}-\overline{V_{j}}\right)}{\partial Q_{j}}=\frac{1}{-\sum_{i \neq j} V_{i} b_{i j} \cos \theta_{i j}} .
$$

（ii）母線電圧の下限制約に関しては,

$$
\frac{\partial Z}{\partial Q_{j}}=\frac{\partial\left(\underline{V}_{j}-V_{j}\right)}{\partial Q_{j}}=\frac{1}{\sum_{i \neq j} V_{i} b_{i j} \cos \theta_{i j}} .
$$

〈2·3 ネットワーク使用料金 $\mathbf{R}$ の算定 有効・無効 電力の価格を短期限界費用による $\rho$ と $\sigma$ により評価し, 発 電機出力を正, 負荷電力を負とすると, 有効および無効潮 流による TAC は次のようになる(11)。

$$
R=-\left[\sum_{i}\left(\rho_{i} P_{i}+\sigma_{i} Q_{i}\right)+\sum_{j}\left(\rho_{j} P_{j}+\sigma_{j} Q_{j}\right)\right]
$$

ここで, $i$ は発電機ノード, $j$ は負荷ノードを示す。

\section{3. 発電機起動停止計画手順}

文献 (6) では送電損失と線路過負荷を考慮した繰り返し 最適化による起動停止計画決定法を提案し，そこでは直流 法最適潮流計算（DC-OPF）を含む優先順位法をべースと するヒューリステックな起動停止計画法を用いていた。起 動停止計画法に関しては優先順位によらない，例えば，ラ グランジュ緩和法など理論的により厳密な手法もあるが(7), 既述のように本論文の主目的が無効電力供給の経済性評価 を含む計画法の開発にあり，ここでは，取り扱いの容易な 文献 (6) の起動停止計画法を用いるものとする。また，次 章で述べる母線電圧制約を考慮した発電機燃料費を目的関 数とする VMC-OPFにより，無効電力を考慮した手法に拡 張する。提案する繰り返し最適化 UCアルゴリズムを以下 に示す。

[Step 1］送電損失と OR 制約を考慮するが，過負荷およ び電圧制約なしの発電機燃料費を目的関数とするセキュリ ティ制約無し最適潮流計算 (NSC-OPF：Non-Security Constrained OPF）により，逐次減少法を用いて ${ }^{(6)}$ 起動停止計 画の初期解を決定する。

[Step 2] 起動停止パターンの初期解に基づいた発電機 利用率により，起動優先順位を決定する。

[Step 3] 初期解に対して, VMC-OPFによる過負荷お よび電圧制約違反の検出と解消を行う。なお, 起動停止の 変更による過負荷解消が必要な場合には, 更新された UC 初期解に対して再び VMC-OPF を実行する。

[Step 4] 起動優先順位により MUT, MDT 制約を満た 
すように，また，過剩な運転予備力の抑制を図るよう UC パターンを修正し，VMC-OPFを実行する。

［Step 5］生成した起動停止パターンにより発電会社の コストと利益を評価する。

[Step 6] (1) 式の目的関数を用いて利益最大化が実現さ れたか否かを判断し，実現できればUCアルゴリズムは終 了。そうでなければStep 7 に行く。

[Step 7] 全ての制約を満足した UC 解から再び発電機 の利用率を求め, 優先順位の更新があれば，Step 3 に戻る。 優先順位に変化がなければ終了。

\section{VMC-OPF アルゴリズム}

現実の系統運用では電圧・無効電力制御により母線電圧 の維持が図られ，一度に複数の電圧制約違反が生じる確率 は低いと考えられるが，ここでは想定外の負荷需要により 制約違反が複数発生する場合も考慮して, 無効電力の最適 な注入箇所および注入量の決定を含む VMC-OPFアルゴリ ズムを以下に示す (図 1 参照)。

[Step 1] 送電損失を無視した発電機出力上下限を制約 とする経済負荷配分 (ELD) により発電機出力の初期解 $P^{\text {old }}$ を算定する。

[Step 2] $\quad P^{\text {old }}$ に基づいた $\mathrm{AC}$ 潮流計算により送電損失 を考慮した ELDにおけるぺナルテイ係数 ${ }^{(8)}\left(P F^{\text {new }}\right)$, 送電 損失 $\left(L^{\text {new }}\right)$ ，拈よびスラック母線の発電機出力 $\left(P_{\text {slack }}\right)$ を 算定する。次に, スラック母線の $P^{\text {old }}$ を新しく求めた $P_{\text {slack }}$ に設定する。

［Step 3］ Step 2で計算した $P F^{\text {new }}$ と $L^{\text {new }}$ により，過負 荷制約のみを考慮した $\mathrm{ELD}^{(6)}$ により発電機出力 $P^{\text {new }}$ を計 算する。

[Step 4] $P^{\text {new }}$ と $P^{\text {old }}$ の差が許容誤差 $(\varepsilon)$ を満足すれば, Step 5 に，そうでなければ $P^{\text {new }}$ を $P^{\text {old }}$ に置き換え， Step 2 に戻る。

[Step 5] もし母線電圧制約違反があれば，次の Step 6 に，なければ OPF は終了する。

[Step 6] ここでは，母線電圧の大きさを維持するため に供給する無効電力の注入ノードを決定する。即ち，電圧 制約違反の最も大きい母線を注入箇所とし，Step 7 により 注入量を決定する。

[Step 7］（19)，(20) 式を用いて, 電圧制約違反を起こし ているノードの $\partial Z / \partial Q$ を求め, 定格電圧と現在值との差 $\Delta V$ から, 次の (22) 式により投入すべき無効電力 $\Delta Q$ を算 定する。

$$
\Delta Q=-\gamma \cdot \Delta V \cdot \frac{1}{\partial Z / \partial Q}
$$

ここで, $\gamma$ は収束加速係数, $\Delta V$ は定格電圧と計算された電 圧の差を示す。

[Step 8］ $\Delta Q$ 供給ノード $k$ の無効電力 $Q$ を更新し, $P^{\text {new }}$ を $P^{\text {old }}$ ，かつ，ノード $k$ の $Q_{k}^{\text {old }}$ を更新された $Q$ に設定して Step 2 に戻る。

なお，提案するVMC-OPF は，主発電会社での発電機出

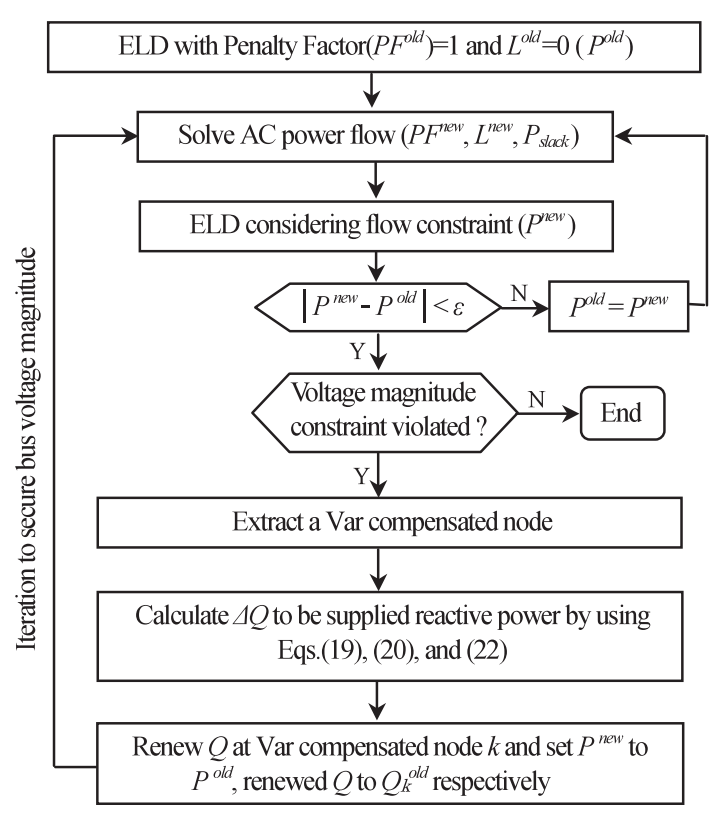

図 1 VMC-OPF $の$ 手順

Fig. 1. VMC-OPF procedure.

力の決定に加えて, 母線電圧制約違反を解消するアンシラ リサービスとしての無効電力供給量を算定するもので，本 論文では電圧維持のため系統運用者により同様な調相容量 投入の決定と供給がなされるものと仮定する。また，市場 参加者が支払うことになる，アンシラリサービス料金 ASC としては, ここでは, 無効電力の LMP と投入量 $\Delta Q$ とか ら，(23)式により評価するものとする。

$$
A=\sum_{k} \sigma \Delta Q
$$

ここで，kは $\Delta Q$ の供給ノードを示す。

\section{5. 試 算 例}

〈5・1〉 モデルシステムＩEEE-118 母線系統を対象に， 発電機起動停止計画決定を検討する。ここで，電力市場に 参加する 36 台の発電機は全て主発電会社に所属し，また， 他の比較的小規模な発電会社からの供給量は既知であると 仮定し，簡単化のため負荷ノードへの注入電力としてこれ らを取り扱うものとする。

次に，IEEE-118 モデル系統において，母線 76 と 118 で の電圧制約違反を想定し，送電線データを付録表 2 に示す ように修正した。発電機特性定数は文献 (9) と同様であるが (付録表 1), 電圧制約違反を考慮して負荷電力と負荷割合を それぞれ付録表 3 と 4 のように設定した。また，負荷の力 率はすべて 0.95 とし，母線電圧の制約は $0.95 \sim 1.05$ (p.u.) とする。線路 75-118での線路容量は 648 MW と仮定し, 他の線路での容量は $700 \mathrm{MW}$ に設定している。運転予備率 は系統負荷の $5 \%$ とし, TAC と ASC における需要家と発電 側の分担割合の一例として，v=1.0 および $\alpha=0.5$ の場合 について考察する。 


\section{Time Interval (h)}

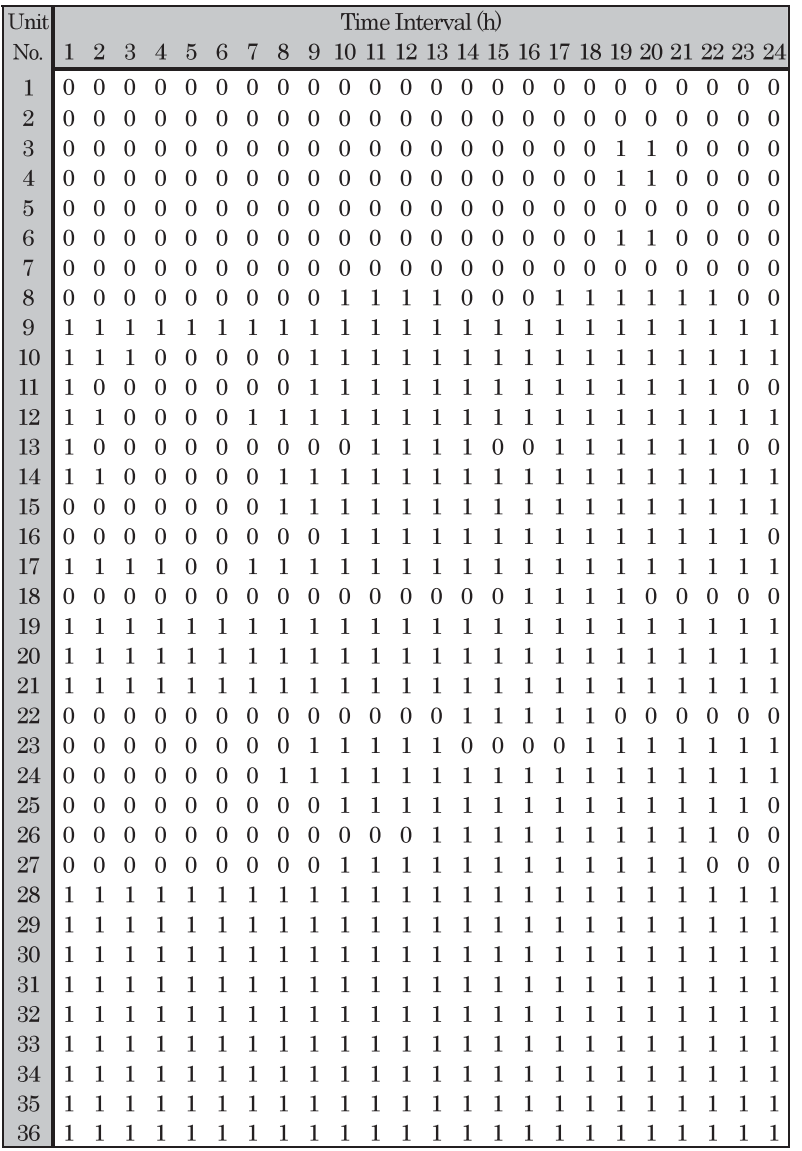

図 2 利益最大化の運用から得られる UCパターン

Fig. 2. UC pattern obtained from benefit maximized method.

表 1 母線電圧の改善 (p.u.)

Table 1. Improvement of bus voltage (p.u.).

\begin{tabular}{|c||c|c||c|c|}
\hline \multirow{2}{*}{ Time interval } & \multicolumn{2}{c||}{ Without voltage constraint } & \multicolumn{2}{c|}{ With voltage constraint } \\
\cline { 2 - 5 } & Node 76 & Node 118 & Node 76 & Node 118 \\
\hline \hline 18 & 0.94721 & 0.94872 & 0.95029 & 0.95078 \\
\hline 19 & 0.94792 & 0.94947 & 0.95007 & 0.95091 \\
\hline 20 & 0.94893 & 0.95039 & 0.95013 & 0.95119 \\
\hline
\end{tabular}

\section{$\langle\mathbf{5} \cdot \mathbf{2}\rangle$ 最適運用計画}

$\langle\mathbf{5} \cdot \mathbf{2} \cdot \mathbf{1}\rangle \quad$ 電圧制約のみを考慮する場合

図 2 に電圧 制約のみを考慮する場合の利益最大化を目的とする UCパ ターンを示すが $(1$ : 運転, 0 : 停止), 後述の線路潮流と電圧 制約を考慮する場合も図 2 と同様のパターンとなっている。

表 1 には電圧制約違反母線での電圧改善を示す。本論文 では, 電圧制約違反が発生する負荷母線には電圧維持に必要 な容量を有する調相設備があり制約違反を処理するものと しているが，第 $18 ， 19 ， 20$ 時間帯において，母線 76 と 118 において電圧の低下がみられ，母線 76 にそれぞれ 34.112, 23.775，13.452 MVar の無効電力を供給することにより電 圧制約違反が解消できた。表 2 と図 3 に，第 18 時間帯に おける VMC-OPFによる電圧修正過程の一例を示す。表 3 に, 電圧制約考慮の前後における発電会社のコストと収入を 示す。電圧下限值の制約違反が発生する場合，図 3 に示す
表 2 第 18 時間帯における電圧修正過程

Table 2. Voltage modification process at $18^{\text {th }}$ time period.

\begin{tabular}{|c||cc||cc|}
\hline \multicolumn{1}{|c||}{} & \multicolumn{2}{c||}{ Node 76 } & \multicolumn{2}{c|}{ Node 118 } \\
\hline \hline Iteration & Voltage (p.u) & $|\triangle Q|$ (MVar) & Voltage (p.u) & $|\triangle Q|$ (MVar) \\
\hline \hline Start & 0.94721 & 0.0 & 0.94872 & 0.0 \\
1 & 0.94753 & 3.502 & 0.94894 & 0.0 \\
2 & 0.94784 & 3.480 & 0.94914 & 0.0 \\
3 & 0.94815 & 3.461 & 0.94935 & 0.0 \\
4 & 0.94846 & 3.441 & 0.94955 & 0.0 \\
5 & 0.94877 & 3.421 & 0.94977 & 0.0 \\
6 & 0.94908 & 3.401 & 0.94997 & 0.0 \\
7 & 0.94939 & 3.381 & 0.95018 & 0.0 \\
8 & 0.94969 & 3.361 & 0.95037 & 0.0 \\
9 & 0.94998 & 3.342 & 0.95057 & 0.0 \\
10 & 0.95029 & 3.322 & 0.95078 & 0.0 \\
\hline
\end{tabular}

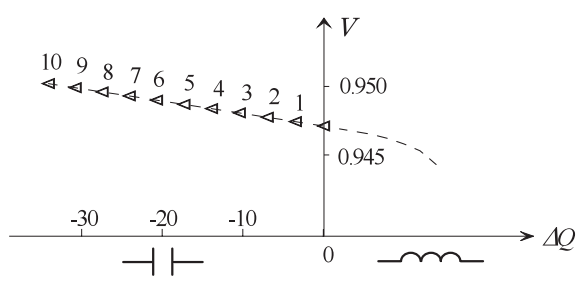

図 3 ノード 76 での $\Delta Q$ による電圧修正過程

Fig. 3. Voltage modification process by $\Delta Q$ at node 76 .

表 3 主発電会社のコストと収益

Table 3. Cost and benefit of Genco.

\begin{tabular}{|c||c||c|}
\hline & Without voltage constraint & With voltage constraint \\
\hline \hline Fuel Cost $(\$)$ & $1,477,623.9$ & $1,477,589.8$ \\
\hline Start-up Cost $(\$)$ & $3,030.0$ & $3,030.0$ \\
\hline RTAC $(\$)$ & $20,256.0$ & $20,310.5$ \\
\hline QTAC $(\$)$ & $27,445.4$ & $27,577.4$ \\
\hline Total TAC $(\$)$ & $47,701.4$ & $47,887.9$ \\
\hline ASC G $(\$)$ & 0.0 & 574.4 \\
\hline Total Cost $(\$)$ & $1,528,355.3$ & $1,529,082.1$ \\
\hline Total Income $(\$)$ & $2,458,078.5$ & $2,458,043.5$ \\
\hline Total Benefit $(\$)$ & $929,723.2$ & $928,961.4$ \\
\hline
\end{tabular}

${ }^{R}$ indicates real power; $Q$ indicates reactive power; $G$ indicates shared by Genco

表 4 線路 75-118 での電力潮流

Table 4. Power flow on line 75-118(MW).

\begin{tabular}{|c||c||c|}
\hline Time interval & Without flow constraint & With flow constraint \\
\hline \hline $\mathrm{t}=18$ & 650.5 & 647.8 \\
\hline
\end{tabular}

進相無効電力の投入により系統の有効電力損失が $1.5 \mathrm{MW}$ 減少し, 主発電会社の有効電力の発電量, 燃料費が減少し ているものの, TACの増加およびアンシラリサービスに対 する ASC を分担することから, 収益が若干減少している と理解される。

$\langle\mathbf{5} \cdot \mathbf{2} \cdot \mathbf{2}\rangle$ 電圧および線路潮流制約を考慮する場合＼cjkstart本 論文では, 文献 (6) の線路過負荷の処理法を用いて過負荷 を解消するが，具体例として，重負荷となる第 18 時間帯 における線路過負荷の発生に対しては, 並列発電機 22２7 の出力調整により線路 75-118 での潮流を表 4 に示すよう に減少することができた。

表 5 には利益最大化と後述のコスト最小化の場合につい て，線路潮流と電圧制約を考慮した主発電会社のコストと 
表 5 線路潮流と電圧制約を考慮した場合の 主発電会社のコストと収益

Table 5. Cost and benefit of Genco with flow and voltage constraints.

\begin{tabular}{|c||c||c|}
\hline & Proposed method & Cost minimized method \\
\hline \hline Fuel Cost $(\$)$ & $1,477,600.9$ & $1,466,750.2$ \\
\hline Start-up Cost $(\$)$ & $3,030.0$ & $2,950.0$ \\
\hline R TAC $(\$)$ & $22,664.1$ & $18,394.3$ \\
\hline QTAC $(\$)$ & $27,552.0$ & $24,773.5$ \\
\hline Total TAC $(\$)$ & $50,216.1$ & $43,167.8$ \\
\hline ASC 9 (\$) & 546.8 & 758.3 \\
\hline Total Cost $(\$)$ & $1,531,393.8$ & $1,513,626.3$ \\
\hline Total Income $(\$)$ & $2,457,589.0$ & $2,381,430.5$ \\
\hline Total Benefit $(\$)$ & $926,195.2$ & $867,804.2$ \\
\hline
\end{tabular}

${ }^{\mathrm{R}}$ indicates real power; $\mathrm{Q}$ indicates reactive power; $\mathrm{G}$ indicates shared by Genco

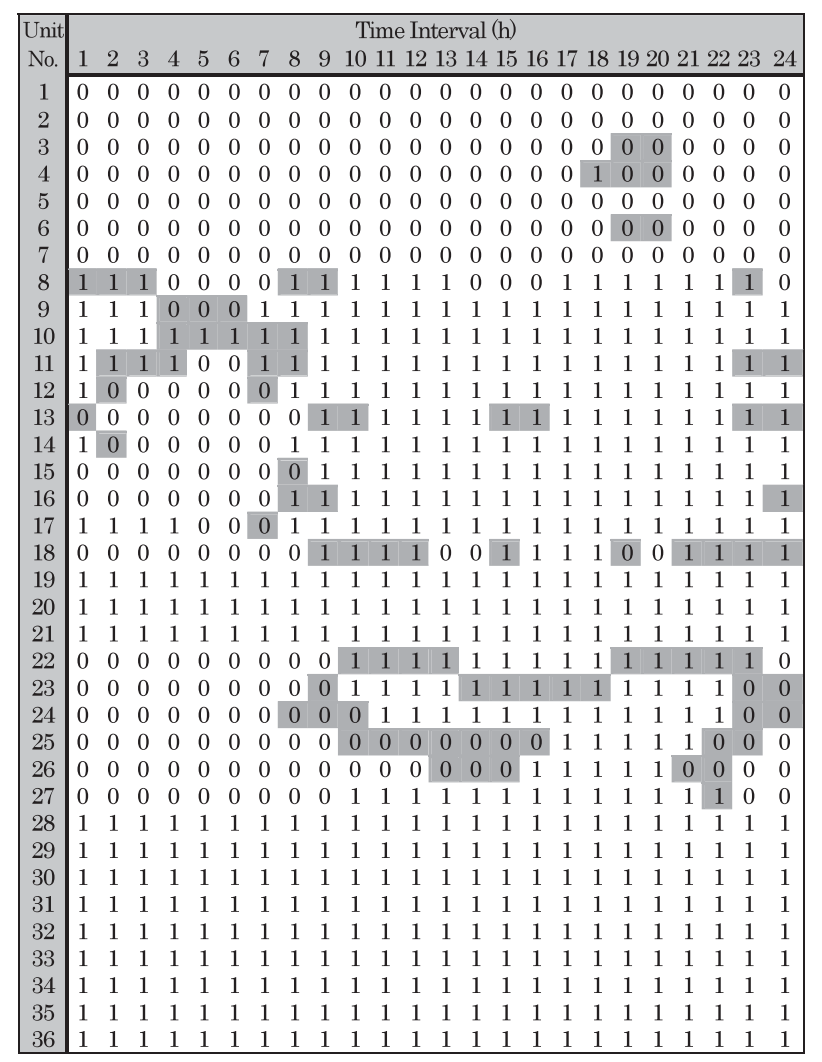

図 4 コスト最小化の運用計画から求めた UCパターン

Fig. 4. UC pattern obtained form cost minimized method.

収益を示している。電圧制約のみの表 3 と比較べ，両制約 を考慮することにより, TAC は過負荷解消のため増加し, また，ASC はLMPの変化により減少しているが，結果的 に主発電会社の総コストは $0.15 \%$ 増加し, 利益も $0.3 \%$ 減少 していることがわかる。

$\langle\mathbf{5} \cdot \mathbf{3}\rangle$ コスト最小化の運用計画との比較 最後に, コ スト最小化を目的とする従来の発電計画法と提案する最適 運用計画の比較を行い, 両者の相違を考察する。図 4 に目 的関数 (1) でのマイナス項に関するコスト最小化の運用計 画での UC パターンを示すが，黒く囲った部分は図 2 の利 益最大化パターンとの相違箇所を示している。また，表 5 に示すように，コスト最小化の運用計画により主発電会社
表 6 第 13 時間帯に扔ける検討結果

Table 6. Simulation results at $13^{\text {th }}$ time period.

\begin{tabular}{|c|c|c|c|c|c|c|}
\hline & \multicolumn{3}{|c|}{ Proposed method } & \multicolumn{3}{|c|}{ Cost minimized method } \\
\hline Fuel Cost (\$) & \multicolumn{3}{|c|}{$71,268.7$} & \multicolumn{3}{|c|}{$71,035.2$} \\
\hline $\mathrm{TAC}(\$)$ & \multicolumn{3}{|c|}{$1,875.9$} & \multicolumn{3}{|c|}{$1,964.6$} \\
\hline Sum (\$) & \multicolumn{3}{|c|}{$73,144.6$} & \multicolumn{3}{|c|}{$72,999.8$} \\
\hline Unit & $\begin{array}{l}\text { Output } \\
\text { (MW) }\end{array}$ & $\begin{array}{c}\rho \\
(\$ / M W h)\end{array}$ & $\begin{array}{c}\text { Income } \\
(\$)\end{array}$ & $\begin{array}{l}\text { Output } \\
\text { (MW) }\end{array}$ & $\begin{array}{c}\rho \\
(\$ / M W h)\end{array}$ & $\begin{array}{c}\text { Income } \\
(\$)\end{array}$ \\
\hline 22 & 0.0 & - & 0.0 & 148.4 & 20.29 & 3011.0 \\
\hline 23 & 115.3 & 23.64 & 2725.7 & 154.8 & 20.24 & 3133.2 \\
\hline 24 & 137.4 & 23.76 & 3264.6 & 72.5 & 20.30 & 1471.8 \\
\hline 25 & 68.95 & 23.50 & 1620.3 & 0.0 & - & 0.0 \\
\hline 26 & 72.0 & 23.53 & 1694.2 & 0.0 & - & 0.0 \\
\hline 27 & 128.1 & 23.53 & 3014.2 & 147.8 & 20.17 & 2981.1 \\
\hline Sum & 521.8 & - & 12319.0 & 523.5 & - & 10597.1 \\
\hline
\end{tabular}

表 7 線路潮流と電圧制約を考慮した場合の起動優先順位

Table 7. Priority order with flow and voltage constraints.

\begin{tabular}{|c|c|c|}
\hline \multirow{6}{*}{ 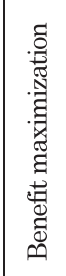 } & Unit No. & 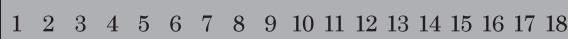 \\
\hline & Initial order & $1720191514163433 \quad 3532 \quad 8 \quad 2113$ \\
\hline & Final order & $9323634333528312129 \quad 9 \quad 17 \quad 1012 \quad 15 \quad 14$ \\
\hline & Unit No & 5 2627282930313233343536 \\
\hline & Initia & 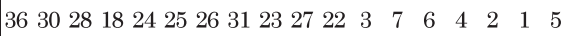 \\
\hline & Final & 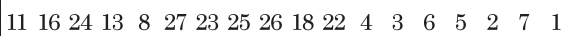 \\
\hline \multirow{6}{*}{ 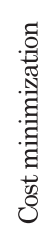 } & Unit No. & 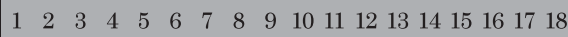 \\
\hline & Initial order & 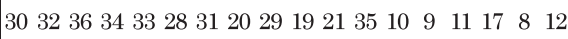 \\
\hline & Final order & 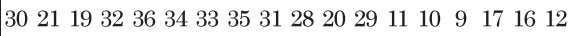 \\
\hline & Unit No. & 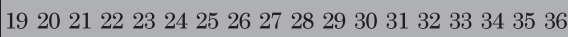 \\
\hline & Initial order & 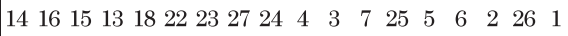 \\
\hline & Final or & $23242526 \quad 4 \quad 5 \quad 3 \quad 2 \quad 6 \quad 7 \quad 1$ \\
\hline
\end{tabular}

の運用コストの最小化が実現できるが，利益は減少してい る。即ち, 同表から, 利益最大化の計画ではコスト最小化 に比べ運用コスト的には多少の増加 $(1.17 \%)$ があるもの の，利益は $6.73 \%$ 向上していることが分かる。

以下に，第 13 時間带を例として，この原因について考 察する。表 6 には，第 13 時間帯に扔ける利益最大化招よ びコスト最小化によるシミュレーション結果を示している が，ここで，ユニット (Unit) は運用計画法の違いにより出 力が異なる発電機を意味する。同表に示すように，提案手 法はコスト最小化の運用計画に比べ, LMPがより高くなる ように並列発電機を生成し, かつ, 収入が $16.2 \%$ 増になっ ていることがわかる。また，出力が同じである残りの 30 台 の発電機の LMP の平均值をみると, 提案手法とコスト最 小化の運用計画の場合, それぞれ $23.73,20.19 \$ / M W h$ と なり，このことも利益追求の最適運用計画がコスト最小化 の計画に比べ利益が大幅に増加する一因になっていると考 えられる。な扔, 表 7 には提案手法とコス卜最小化の運用 計画の場合での初期 UC パターンから求めた順位（初期順 位）および起動停止計画が終了した時点での順位（最終順 位）を示す。同表に示すように, 運用手法の相違による初 期順位の变化は最終順位の決定に影響し, 図 2 お よび図 4 に示す起動停止パターンの変化にも繋がっている。 


\section{6. まとめ}

有効電力の地点別限界価格によって電力価格が決定され る場合を想定し，市場に参加する発電会社の利益最大化を 目的とした発電計画策定に関し，無効電力を考慮した日間 の発電機起動停止計画法を提案した。即ち，電圧制約違反 処理を含む最適潮流計算アルゴリズム（VMC-OPF）を開発 し，調相設備による母線電圧維持に対するアンシラリサー ビス料金（ASC）と無効潮流を考慮したネットワーク使用 料金（TAC）をコスト関数に導入することにより，無効電 力の経済性を評価した起動停止計画決定法を示している。

提案手法により，従来の起動停止計画法では取り上げら れなかった電圧制約違反の処理や無効潮流考慮による発電 計画決定への影響評価, 即ち, 調相容量の注入による電圧維 持に係るアンシラリサービス料金の評価や，ネットワーク 使用料金への影響評価など，電力市場における無効電力供 給の経済性評価が可能となり，また，コスト最小化運用と の相違を具体的に把握することができた。ここでは，LMP による収入を想定し利益最大化を目的に発電機の運用を決 定しているが，市場への電力供給量と市場決済価格とから 収入が予め想定される場合には，利益の最大化に繋がる最 小コスト運用計画の決定にも提案手法の適用が可能である。

最後に，電圧制約違反処理に関して，試算例では制約違 反母線が二箇所の場合の対応例を示したが，多数の制約違 反が同時に発生する際，提案法では必ずしも迅速に処理で きるという保証がなく，今後，多重違反に対する効率的な 電圧制約処理法，更には，変圧器タップ切替や無効電力供 給量制約を考慮した制約処理アルゴリズムの開発が期待さ れる。

(平成 17 年 5 月 6 日受付，平成 18 年 3 月 22 日再受付)

\section{文献}

(1) G. Zhao, M. Iguchi, and S. Yamashiro: "A Study on Unit Commitment by Using Short Run Marginal Cost", The Papers of Joint Technical Meeting on Power Engineering and Power System Engineering, IEE Japan, PE-01-79, PSE-01-73, pp.23-28 (2001-9) (in Japanese)

趙 国梁・井口 傑・山城 迪：「短期限界費用を用いた火力発電 機起動停止計画に関する一考察」, 電気学会電力技術・電力系統技術 合同研資, PE-01-79, PSE-01-73, pp.23-28 (2001-9)

(2) S. Hunt and G. shuttleworth: "Competition and Choice in Electricity", IEEE Spectrum, pp.20-31 (1996-7)

(3) H. Rudick: "Pioneering Electricity Reform in South America", IEEE Spectrum, pp.38-44 (1996-8)

(4) T. Hatta and M. Tanaka: Liberalizing Electricity Markets: An Economic Analysis, toyokeizai Inc. (2004) (in Japanese)

八田達夫 ·田中 誠: 電力自由化の経済学, 東洋経済新聞社 (2004)

(5) S. Yamashiro, F. Asher, T. Uchiyuki, Y. Nakamura, T. Honma, and S. Senzaki: "A Method for Weekly Thermal Unit Commitment Scheduling", T. IEE Japan, Vol.114-B, No.12, pp.1236-1242 (1994-12) (in Japanese) 山城 迪・アッシャー・内山敏之・中村陽一・本間 武·先崎照治:「火 力発電機群の週間起動停止計画法」, 電学論 B, 114, 12, pp.1236-1242 (1994-12)

(6) G. Zhao and S. Yamashiro: "A Method for Unit Commitment with Transmission Losses and Flow Constraint", T. IEE Japan, Vol.122-B, No.3, pp.359-368 (2002-3) (in Japanese)

趙 国梁・山城 迪:「送電損失と線路過負荷を考慮した火力発電 機起動停止計画手法」,電学論 B, 122,3,pp.359-368 (2002-3)
(7) D. Murata and S. Yamashiro: "Unit Commitment Scheduling by Lagrange Relaxation Method Taking into Account Transmission Losses", IEEJ Trans. $P E$, Vol.124, No.4, pp.546-552 (2004-4) (in Japanese)

村田大介・山城＼cjkstart迪：「送電損失を考慮したラグランジュ緩和法によ る火力発電機の起動停止計画」, 電学論 B, 124, 4, pp.546-552 (2004-4)

(8) A.J. Wood and B.F. Wollenberg: Power Generation Operation, and Control, Second Edition, John Wiley \& Sons. Inc. (1996)

(9) H. Ma and S.M. Shahidehpour: "Unit Commitment with Transmission Security and Voltage Constraints", IEEE Trans. Power Syst., Vol.14, No.2, pp.757-764 (1999-5)

10) S. Wu and S. Yamashiro: "An Economic Estimation of Reactive Power Supply Based on Marginal Cost", Proc. of the ICEE 2002, Vol.I, pp.440-445 (2002)

(11) M. Caramanis, R. Bohn, and F. Scheweppe: "Optimal Spot Pricing : Practice and Theory", IEEE Trans. Power Apparatus Syst., Vol.PAS-101, No.9, pp.3234-3245 (1982-9)

(12) H.H. Happ: "Optimal Power Dispatch", IEEE Trans. Power Apparatus Syst., Vol.PAS-92, pp.820-830 (1973-10)

(13) S. Yamashiro: "Optimization of Power Flow by DC Method", T. IEE Japan, Vol.97-B, No.11, pp.679-684 (1977-11) (in Japanese)

山城 迪：「直流法による電力潮流最適化」, 電学論 B, 97, 11, pp.31-36 (1977-11)

\section{付 録}

\section{IEEE-118 BUS SYSTEM DATA}

付表 1 発電機特性定数

app. Table 1. Characteristic constant of unit.

\begin{tabular}{|c|c|c|c|c|c|c|c|c|c|c|}
\hline \multirow{2}{*}{$\begin{array}{l}\text { Unit } \\
\text { No. }\end{array}$} & \multicolumn{3}{|c|}{$\begin{aligned} F= & a+b P+c P^{2} \\
& (\$ / M W h)\end{aligned}$} & \multicolumn{2}{|c|}{$\begin{array}{l}\text { Output } \\
\text { (MW) }\end{array}$} & \multirow{2}{*}{$\begin{array}{l}\mathrm{M} \\
\mathrm{U} \\
\mathrm{T}\end{array}$} & \multirow{2}{*}{$\begin{array}{l}\mathrm{M} \\
\mathrm{D} \\
\mathrm{T}\end{array}$} & \multirow{2}{*}{$\begin{array}{l}\text { Initial } \\
\text { state }\end{array}$} & \multirow{2}{*}{$\begin{array}{l}\text { SUC } \\
(\$ / h)\end{array}$} & \multirow{2}{*}{ Bus } \\
\hline & a & $b$ & $c$ & $\underline{P}$ & $\bar{P}$ & & & & & \\
\hline 1 & 24.389 & 25.547 & 0.0253 & 2.4 & 12 & 1 & 1 & $\cdot 1$ & 0 & 31 \\
\hline 2 & 118.91 & 37.964 & 0.0156 & 4 & 20 & 1 & 1 & -1 & 30 & 46 \\
\hline 3 & 118.46 & 37.777 & 0.0136 & 4 & 20 & 1 & 1 & $\cdot 1$ & 30 & 46 \\
\hline 4 & 118.91 & 37.964 & 0.0116 & 4 & 20 & 1 & 1 & $\cdot 1$ & 30 & 103 \\
\hline 5 & 119.46 & 38.777 & 0.0106 & 4 & 20 & 1 & 1 & $\cdot 1$ & 30 & 87 \\
\hline 6 & 117.76 & 37.551 & 0.012 & 4 & 20 & 1 & 1 & $\cdot 1$ & 30 & 31 \\
\hline 7 & 118.11 & 37.664 & 0.0126 & 4 & 20 & 1 & 1 & $\cdot 1$ & 30 & 111 \\
\hline 8 & 81.826 & 13.507 & 0.0096 & 15.2 & 76 & 3 & 2 & 3 & 80 & 12 \\
\hline 9 & 81.136 & 13.327 & 0.0088 & 15.2 & 76 & 3 & 2 & 3 & 80 & 12 \\
\hline 10 & 81.298 & 13.354 & 0.009 & 15.2 & 76 & 3 & 2 & 3 & 80 & 69 \\
\hline 11 & 81.626 & 13.407 & 0.0093 & 15.2 & 76 & 3 & 2 & 3 & 80 & 54 \\
\hline 12 & 217.9 & 18 & 0.0062 & 25 & 100 & 4 & 2 & 5 & 100 & 25 \\
\hline 13 & 219.78 & 18.6 & 0.006 & 25 & 100 & 4 & 2 & 5 & 100 & 26 \\
\hline 14 & 218.34 & 18.1 & 0.0061 & 25 & 100 & 4 & 2 & 5 & 100 & 65 \\
\hline 15 & 216.78 & 18.28 & 0.0059 & 25 & 100 & 4 & 2 & -3 & 100 & 66 \\
\hline 16 & 218.78 & 18.2 & 0.006 & 25 & 100 & 4 & 2 & -3 & 100 & 100 \\
\hline 17 & 216.78 & 17.28 & 0.0058 & 25 & 100 & 4 & 2 & -3 & 100 & 111 \\
\hline 18 & 218.78 & 19.2 & 0.007 & 25 & 100 & 4 & 2 & -3 & 100 & 103 \\
\hline 19 & 143.03 & 10.715 & 0.0047 & 54.25 & 155 & 5 & 3 & 5 & 200 & 10 \\
\hline 20 & 143.32 & 10.737 & 0.0048 & 54.25 & 155 & 5 & 3 & 5 & 200 & 49 \\
\hline 21 & 143.6 & 10.758 & 0.0049 & 54.25 & 155 & 5 & 3 & 5 & 200 & 49 \\
\hline 22 & 259.13 & 23 & 0.0026 & 68.95 & 197 & 5 & 4 & -4 & 300 & 25 \\
\hline 23 & 259.65 & 23.1 & 0.0026 & 68.95 & 197 & 5 & 4 & -4 & 300 & 59 \\
\hline 24 & 260.18 & 23.2 & 0.0026 & 68.95 & 197 & 5 & 4 & -4 & 300 & 61 \\
\hline 25 & 260.58 & 23.4 & 0.0026 & 68.95 & 197 & 5 & 4 & -4 & 300 & 80 \\
\hline 26 & 261.18 & 23.5 & 0.0027 & 68.95 & 197 & 5 & 4 & -4 & 300 & 89 \\
\hline 27 & 260.08 & 23.04 & 0.0026 & 68.95 & 197 & 5 & 4 & -4 & 300 & 69 \\
\hline 28 & 176.06 & 10.842 & 0.0015 & 140 & 350 & 8 & 5 & 10 & 500 & 11 \\
\hline 29 & 177.06 & 10.862 & 0.0015 & 140 & 350 & 8 & 5 & 10 & 500 & 31 \\
\hline 30 & 176.06 & 10.662 & 0.0014 & 140 & 350 & 8 & 5 & 10 & 500 & 49 \\
\hline 31 & 177.96 & 10.962 & 0.0016 & 140 & 350 & 8 & 5 & 10 & 500 & 89 \\
\hline 32 & 310 & 7.4921 & 0.0019 & 100 & 400 & 8 & 5 & 10 & 800 & 65 \\
\hline 33 & 311.91 & 7.5031 & 0.002 & 100 & 400 & 8 & 5 & 10 & 800 & 66 \\
\hline 34 & 312.91 & 7.5121 & 0.002 & 100 & 400 & 8 & 5 & 10 & 800 & 69 \\
\hline 35 & 314.9 & 7.5321 & 0.002 & 100 & 400 & 8 & 5 & 10 & 800 & 80 \\
\hline 36 & 313.91 & 7.6121 & 0.002 & 100 & 400 & 8 & 5 & 10 & 800 & 89 \\
\hline
\end{tabular}

*FS $=\mathrm{SUC} \times \tau$ ( $\tau:$ down time $) ;$ Bus indicates generator connected node 
付表 2 送電線特性定数 (\%)

app. Table 2. Transmission line data (percent value).

\begin{tabular}{|c|c|c|c|c|c|c|c|c|c|c|c|c|c|c|}
\hline & $j$ & $r$ & $x$ & $c / 2$ & 1 & $J$ & $r$ & $x$ & $c / 2$ & 1 & $J$ & $r$ & $x$ & $c / 2$ \\
\hline & 2 & 3.03 & $\overline{999}$ & 0.0 & 444 & 45 & 2.24 & 900 & 0.0 & 68 & \begin{tabular}{|l|}
81 \\
\end{tabular} & 0.175 & \begin{tabular}{|l|l|}
2.02 \\
\end{tabular} & 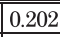 \\
\hline & 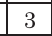 & 1.29 & & & & 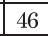 & & & 0.0 & 81 & 80 & & 3.7 & \\
\hline & 5 & .176 & $07:$ & 00 & 46 & 47 & 38 & 12.7 & 0.0 & 77 & 82 & 98 & 85 & \\
\hline & 5 & 2.41 & 10. & 0. & 46 & 48 & 6.01 & 18.9 & .0 & \begin{tabular}{|l|}
82 \\
\end{tabular} & 83 & 1.12 & 3.6 & 0.0 \\
\hline & 6 & 1.19 & 5.4 & 0.0 & 47 & 49 & 91 & 25 & 0 & \begin{tabular}{|l|}
83 \\
\end{tabular} & \begin{tabular}{|l|}
84 \\
\end{tabular} & 6.25 & 13.2 & .0 \\
\hline & 7 & 0.459 & \begin{tabular}{|l|}
2.08 \\
\end{tabular} & 0.208 & 42 & 49 & & 16.1 & & \begin{tabular}{|l|}
83 \\
\end{tabular} & 85 & & & \\
\hline & 9 & 244 & & & & 49 & & 18.6 & 0.0 & \begin{tabular}{|l|}
84 \\
\end{tabular} & 85 & 302 & 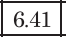 & \\
\hline & 5 & 0.0 & \begin{tabular}{|l|}
2.6 \\
\end{tabular} & 0.0 & 18 & 49 & 79 & 5.05 & 0.50 & \begin{tabular}{|l|}
85 \\
\end{tabular} & 86 & 3.5 & 12 & 30 \\
\hline 9 & \begin{tabular}{|l|}
10 \\
\end{tabular} & 0.258 & \begin{tabular}{|l|l|}
3.22 \\
\end{tabular} & 0.0 & 49 & 50 & 67 & 7.52 & 0.0 & 86 & 87 & 2.828 & 20. & 2.0 \\
\hline & 11 & 2.09 & 6.8 & 0.0 & 49 & 51 & & 13.7 & 0.0 & 85 & 88 & .0 & \begin{tabular}{|l|l}
10.2 \\
\end{tabular} & .0 \\
\hline$b$ & 11 & 2.03 & \begin{tabular}{|l|}
6.82 \\
\end{tabular} & 0.0 & 51 & 52 & 2.03 & 5.88 & 0.0 & 85 & 89 & & 11 & \\
\hline & 12 & 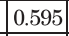 & & 0.196 & & 53 & & 16.35 & 0 & 88 & 89 & & 7.12 & \\
\hline & \begin{tabular}{|l|}
12 \\
\end{tabular} & 87 & 6.16 & 0. & 53 & 54 & 63 & 12.2 & 0.0 & \begin{tabular}{|l|}
89 \\
\end{tabular} & 90 & 1.58 & \begin{tabular}{|l}
6. \\
\end{tabular} & \\
\hline 3 & 12 & 4.84 & 16.0 & 0.0 & 49 & 54 & 98 & 14.5 & .0 & \begin{tabular}{|l|}
90 \\
\end{tabular} & 91 & 54 & 8.3 & 0.0 \\
\hline 7 & 12 & $|0.862|$ & 3. & 0.1 & 54 & 55 & 1.69 & 7.07 & 0.0 & \begin{tabular}{|l|}
89 \\
\end{tabular} & 92 & 79 & 3.8 & .38 \\
\hline & 13 & 2.225 & \begin{tabular}{|l|}
7.31 \\
\end{tabular} & 0.0 & 54 & 56 & 0.275 & 0.955 & 0.0 & 91 & 92 & 87 & 12.7 & .0 \\
\hline & 14 & 15 & 7.0 & 0. & & 56 & \begin{tabular}{|l|l|}
0.488 \\
\end{tabular} & 1.51 & 0.15 & 92 & 93 & 2.58 & 8. & \\
\hline & 1 & 44 & 24.44 & 0.0 & 56 & 57 & 43 & 9.66 & 0.0 & \begin{tabular}{|l|}
92 \\
\end{tabular} & 94 & 1.81 & 15. & \\
\hline 14 & 15 & 5.95 & 19.5 & 0. & 50 & \begin{tabular}{|l|}
57 \\
\end{tabular} & 74 & 13. & & 93 & 92 & 2.23 & \begin{tabular}{|l}
7.32 \\
\end{tabular} & 0.0 \\
\hline 12 & 16 & 2.12 & 8.34 & 0.0 & 56 & \begin{tabular}{|l|}
58 \\
\end{tabular} & 43 & 9.66 & 0.0 & \begin{tabular}{|l|}
94 \\
\end{tabular} & 95 & 32 & 4. & 0.0 \\
\hline 15 & 1 & 1.32 & 4.37 & 0.437 & 51 & $t$ & \begin{tabular}{|l|}
2.55 \\
\end{tabular} & 7.19 & .0 & \begin{tabular}{|l|}
80 \\
\end{tabular} & 96 & 3.56 & 18 & 0.0 \\
\hline 16 & 17 & 4.54 & \begin{tabular}{|l|}
18.01 \\
\end{tabular} & \begin{tabular}{|l||}
0.0 \\
\end{tabular} & 54 & \begin{tabular}{|l|}
59 \\
\end{tabular} & 53 & 22.9 & 0.0 & \begin{tabular}{|l|}
82 \\
\end{tabular} & 96 & 1.62 & 0. & \\
\hline 17 & 18 & 1.23 & 5.0 & 0. & 56 & 59 & 07 & 12.0 & 0.0 & \begin{tabular}{|l|}
94 \\
\end{tabular} & \begin{tabular}{|l|}
96 \\
\end{tabular} & 69 & 8.65 & .0 \\
\hline 18 & g. & 1. & 4.0 & 0. & 55 & \begin{tabular}{|l|}
59 \\
\end{tabular} & \begin{tabular}{|l|l|}
4.739 \\
\end{tabular} & 21.58 & 0.0 & \begin{tabular}{|l|}
80 \\
\end{tabular} & 97 & 1.83 & 9. & .0 \\
\hline 19 & 20 & 2.52 & \begin{tabular}{|l|}
11.7 \\
\end{tabular} & 0.0 & 59 & \begin{tabular}{|l|}
60 \\
\end{tabular} & 17 & 14.5 & 0.0 & \begin{tabular}{|l|}
80 \\
\end{tabular} & \begin{tabular}{|l|}
98 \\
\end{tabular} & 38 & 10. & 0.0 \\
\hline 15 & 1 & 1.2 & 3.94 & 0.0 & 59 & $61 \mid$ & 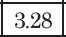 & 15.0 & 0.0 & 80 & \begin{tabular}{|l|l} 
\\
\end{tabular} & 54 & 20 & 0. \\
\hline 20 & 21 & 1.83 & 8.4 & 0. & 30 & \begin{tabular}{|l|}
61 \\
\end{tabular} & \begin{tabular}{|l|l|}
0.264 \\
\end{tabular} & 35 & 0.135 & \begin{tabular}{|l|}
92 \\
\end{tabular} & 100 & 6.48 & 29 & 10 \\
\hline 21 & \begin{tabular}{|l|}
22 \\
\end{tabular} & 2.0 & & & 60 & 62 & 23 & & 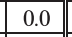 & \begin{tabular}{|l|}
94 \\
\end{tabular} & 100 & & 8 & 0.58 \\
\hline 2 & 2 & 3.42 & 15.9 & 0. & 61 & \begin{tabular}{|l|}
62 \\
\end{tabular} & \begin{tabular}{|l|l|}
0.824 \\
\end{tabular} & 3.76 & 0.0 & 95 & 96 & 1.71 & 5. & 0.0 \\
\hline 2 & 24 & 1.35 & \begin{tabular}{|l|}
4.92 \\
\end{tabular} & 0.492 & 63 & \begin{tabular}{|l|}
59 \\
\end{tabular} & 0.0 & 3.86 & 0.0 & \begin{tabular}{|l|}
96 \\
\end{tabular} & 97 & 1.73 & \begin{tabular}{|l|l}
8.8 \\
\end{tabular} & 0.0 \\
\hline 2 & 2 & 1.56 & 8.0 & \begin{tabular}{|c|}
0.0 \\
\end{tabular} & 63 & 64 & \begin{tabular}{|l|l|}
0.172 \\
\end{tabular} & 2.0 & 12 & 98 & 1100 & 97 & 17 & \\
\hline 26 & 25 & 0. & 3.8 & 0. & 84 & 61 & 0.0 & 2.68 & 0.0 & \begin{tabular}{|l|}
99 \\
\end{tabular} & 100 & 1.8 & 8.1 & 0.0 \\
\hline 25 & 2 & 3. & 16 & & 38 & 65 & & & & 100 & 101 & .77 & 12. & \\
\hline 27 & 8 & 1.9 & 8.5 & 0. & 64 & \begin{tabular}{|l|}
65 \\
\end{tabular} & 0.269 & 3.02 & \begin{tabular}{|l|} 
\\
\end{tabular} & \begin{tabular}{|l|}
92 \\
\end{tabular} & 102 & 1.23 & 5.5 & 0.0 \\
\hline 28 & 29 & 2.37 & 9.43 & 0.0 & 49 & 66 & \begin{tabular}{|l|}
0.9 \\
\end{tabular} & 4.55 & 0.0 & \begin{tabular}{|l|}
101 \\
\end{tabular} & 102 & 2.46 & 11 & 00 \\
\hline 30 & 17 & 0.0 & \begin{tabular}{|l|}
3.88 \\
\end{tabular} & 0. & 62 & 66 & \begin{tabular}{|l|l}
4.82 \\
\end{tabular} & 21.8 & 0.0 & \begin{tabular}{|l|}
100 \\
\end{tabular} & 103 & \begin{tabular}{|l|}
1.6 \\
\end{tabular} & 5.2 & 0.0 \\
\hline 8 & 30 & \begin{tabular}{|l|l|}
0.431 \\
\end{tabular} & \begin{tabular}{|l|l|}
5.04 \\
\end{tabular} & & 62 & 67 & 58 & 11.7 & 0.0 & 100 & 104 & 51 & \begin{tabular}{|l|l}
20.4 \\
\end{tabular} & 0.0 \\
\hline 26 & 5 & 0.7 & 8 & & & \begin{tabular}{|l|}
66 \\
\end{tabular} & & & & 3 & 1 & & & \\
\hline 17 & 31 & 4. & 15.63 & & 36 & 67 & 24 & 10.15 & 0.0 & 3 & 105 & 35 & 1 & 0.0 \\
\hline 29 & 31 & 1.08 & 31 & 0.331 & 65 & 68 & 0.138 & 1.6 & 0.16 & 100 & \begin{tabular}{|l|}
106 \\
\end{tabular} & 6.05 & 22.9 & 0.0 \\
\hline 23 & 32 & 3.17 & 11.53 & 0.1 & 47 & \begin{tabular}{|l|}
69 \\
\end{tabular} & 8.44 & 27.78 & 0.0 & \begin{tabular}{|l|}
104 \\
\end{tabular} & 105 & 0.994 & \begin{tabular}{|l|l|}
3.78 \\
\end{tabular} & 0.37 \\
\hline 31 & \begin{tabular}{|l|}
32 \\
\end{tabular} & 2.9 & 9.8 & 0. & 9 & \begin{tabular}{|l|}
69 \\
\end{tabular} & \begin{tabular}{|l|l|} 
\\
\end{tabular} & 32.4 & 0.0 & 55 & 106 & \begin{tabular}{|l|l} 
\\
\end{tabular} & 5.47 & 0.0 \\
\hline 27 & 3 & \begin{tabular}{|l|l|}
2.29 \\
\end{tabular} & 7.5 & & 68 & \begin{tabular}{|l|}
69 \\
\end{tabular} & 0.0 & & 0 & 5 & 107 & & \begin{tabular}{|l}
18.3 \\
\end{tabular} & 0.0 \\
\hline & 33 & 3.8 & & & & 70 & & 12.7 & 0.0 & 55 & 108 & 61 & 7.0 & \\
\hline 19 & 34 & 7.52 & 24 & & 24 & 70 & . & 41.15 & 0.0 & 66 & 1 & 5.3 & 183 & 00 \\
\hline 35 & 36 & 0.224 & 1.0 & 0.102 & 70 & 71 & \begin{tabular}{|l|l|}
0.882 \\
\end{tabular} & 3.55 & 0.0 & 88 & 109 & 05 & 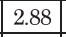 & 0.0 \\
\hline 35 & 37 & 1.1 & 4.8 & 0. & 24 & \begin{tabular}{|l|}
72 \\
\end{tabular} & 4. & 9.6 & .0 & 03 & 110 & 3.906 & 1 & .0 \\
\hline 5. & 37 & 4.12 & 14 & & 71 & 72 & 4. & $\begin{array}{l}18.0 \\
\end{array}$ & 0.0 & 99 & 110 & 78 & 7.62 & 0.4 \\
\hline 3 & 36 & & & & 71 & 73 & 0 & & ח & \begin{tabular}{|l|}
110 \\
\end{tabular} & 111 & & $\begin{array}{ll} \\
\end{array}$ & \\
\hline 34 & 37 & 0.256 & & 0.0 & 70 & 74 & 4.01 & 13.23 & .0 & 110 & 112 & 2.47 & 6.4 & 20 \\
\hline 38 & 37 & 0.0 & \begin{tabular}{|l|l} 
\\
\end{tabular} & 0. & 70 & 75 & 8 & 14.1 & 0.0 & \begin{tabular}{|l|}
17 \\
\end{tabular} & \begin{tabular}{|l|}
113 \\
\end{tabular} & 0.913 & 3.0 & 0.0 \\
\hline 37 & 39 & 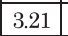 & 10. & & 69 & 75 & 05 & 12.2 & 0.0 & 32 & 113 & 6.15 & 20. & D.0 \\
\hline 3 & 40 & 5.93 & 16 & & 72 & 75 & 1. & 4.06 & 0.0 & \begin{tabular}{|l|}
32 \\
\end{tabular} & \begin{tabular}{|l|l|}
114 \\
\end{tabular} & .35 & \begin{tabular}{|l|l}
6.1 \\
\end{tabular} & 0.0 \\
\hline & 38 & , & & & & 77 & & & & 27 & 115 & 1.64 & \begin{tabular}{|l|l}
7.41 \\
\end{tabular} & \\
\hline & 40 & 1.8 & 6. & & 69 & 77 & 3. & 10.1 & 0.0 & 114 & 115 & \begin{tabular}{|l|}
0.23 \\
\end{tabular} & 104 & 0.104 \\
\hline 40 & 41 & $1.4 t$ & $4.8^{\prime}$ & 0.487 & 75 & 77 & 6.01 & 19.99 & 0.0 & \begin{tabular}{|l|}
68 \\
\end{tabular} & \begin{tabular}{|l|}
116 \\
\end{tabular} & 0.03 & 0.405 & 0.0 \\
\hline 4 & 42 & 5.5 & 18 & 0. & 77 & 78 & 0.376 & 1.24 & 0.0 & 12 & 117 & 29 & 14 & 0.0 \\
\hline 4 & 42 & 4. & & 0. & 18 & 79 & & 2.4 & 0.0 & 75 & 118 & 45 & 4.8 & 0 \\
\hline 43 & 44 & & & & & 80 & & & 0. & 76 & 118 & 64 & 5.4 & \\
\hline & & .10 & & & & & & & & & & & & \\
\hline
\end{tabular}

\section{付表 3 日間負荷 (MW)}

app. Table 3. Daily load data.

\begin{tabular}{|c|c||c|c||c|c||c|c|}
\hline $\mathrm{t}$ & Load & $\mathrm{t}$ & Load & $\mathrm{t}$ & Load & $\mathrm{t}$ & Load \\
\hline \hline 1 & 4242 & 7 & 3898 & 13 & 5245 & 19 & 5618 \\
2 & 4036 & 8 & 4287 & 14 & 5126 & 20 & 5508 \\
3 & 3912 & 9 & 4601 & 15 & 5074 & 21 & 5415 \\
4 & 3766 & 10 & 5186 & 16 & 5108 & 22 & 5283 \\
5 & 3709 & 11 & 5225 & 17 & 5375 & 23 & 4812 \\
6 & 3745 & 12 & 5278 & 18 & 5695 & 24 & 4516 \\
\hline
\end{tabular}

付表 4 各母線の負荷割合

app. Table 4. Load distribution rate (\%) for buses.

\begin{tabular}{|c|c||c|c||c|c||c|c||c|c|}
\hline Node & Rate & Node & Rate & Node & Rate & Node & Rate & Node & Rate \\
\hline \hline 1 & 0.01 & 23 & 0.002 & 48 & 0.009 & 75 & 0.006 & 97 & 0.004 \\
2 & 0.009 & 27 & 0.009 & 49 & 0.01 & 76 & 0.080 & 98 & 0.005 \\
3 & 0.01 & 28 & 0.004 & 50 & 0.008 & 77 & 0.017 & 100 & 0.004 \\
4 & 0.01 & 29 & 0.009 & 51 & 0.009 & 78 & 0.012 & 101 & 0.005 \\
6 & 0.01 & 32 & 0.01 & 52 & 0.009 & 79 & 0.013 & 102 & 0.005 \\
7 & 0.009 & 33 & 0.006 & 53 & 0.01 & 80 & 0.001 & 103 & 0.007 \\
11 & 0.015 & 34 & 0.007 & 54 & 0.02 & 82 & 0.012 & 104 & 0.008 \\
12 & 0.008 & 35 & 0.008 & 55 & 0.022 & 83 & 0.013 & 105 & 0.009 \\
13 & 0.009 & 36 & 0.005 & 56 & 0.019 & 84 & 0.017 & 106 & 0.007 \\
14 & 0.008 & 39 & 0.01 & 57 & 0.015 & 85 & 0.013 & 107 & 0.01 \\
15 & 0.007 & 40 & 0.01 & 58 & 0.015 & 86 & 0.020 & 108 & 0.002 \\
16 & 0.005 & 41 & 0.011 & 59 & 0.01 & 88 & 0.018 & 109 & 0.002 \\
17 & 0.002 & 42 & 0.011 & 60 & 0.01 & 90 & 0.029 & 110 & 0.01 \\
18 & 0.008 & 43 & 0.004 & 62 & 0.019 & 92 & 0.004 & 112 & 0.007 \\
19 & 0.007 & 44 & 0.004 & 66 & 0.015 & 93 & 0.004 & 114 & 0.002 \\
20 & 0.007 & 45 & 0.012 & 67 & 0.019 & 94 & 0.003 & 115 & 0.006 \\
21 & 0.004 & 46 & 0.005 & 70 & 0.015 & 95 & 0.003 & 117 & 0.01 \\
22 & 0.004 & 47 & 0.01 & 74 & 0.008 & 96 & 0.007 & 118 & 0.104 \\
\hline
\end{tabular}

李 相 俊 (学生員) 2001 年 7 月中国瀋陽工業大学電気工

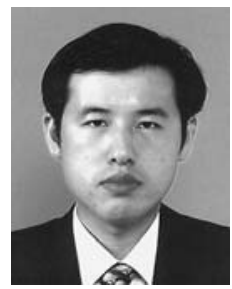
程学院電器専攻卒業。2004 年 3 月北見工業大学 大学院工学研究科電気電子工学専攻博士前期課程 修了。同年 4 月同大学大学院工学研究科システム 工学専攻博士後期課程へ進学, 現在に至る。主に 電力市場環境下における発電計画に関する研究に 従事。IEEE 学生員。

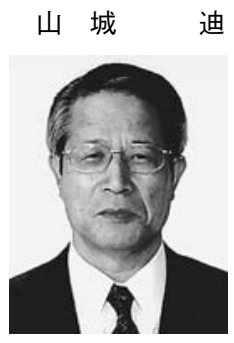

迪（上級会員） 1963 年 3 月北海道大学工学部電気 工学科卒業。1967 年 3 月同大学大学院工学研究 科修士課程修了。1971 年 4 月北見工業大学助教 授，1978 年 6 月同教授，現在に至る。工学博士。 電力系統工学, 電力工学の研究に従事。電気設備 学会, 日本太陽エネルギー学会, 火力原子力発電 協会, IEEE 会員。 